\title{
MEMBEBASKAN POSITIVISME HUKUM KE RANAH HUKUM PROGRESIF (Studi Pembacaan Teks Hukum Bagi Penegak Hukum)
}

\author{
A. Sukris Sarmadi \\ Fakultas Syariah IAIN Antasari Banjarmasin \\ E-mail: a.sukris@yahoo.co.id
}

\begin{abstract}
According to the law of UU No. 48 Year 2009 about J udicial Power Section 5 sentence (1) which is on its say; core express that judge is obliged to dig of law, following, and comprehending values law and sense of justice which live in society. Hence law shall comprehend to place forward sense of justice which live in society. Law have the target of its social, advocating and protecting society citizen. If text in law at variance with target of social hence text in law that have to be transferred in essence norm that at target of its social in the form of society sense of justice, defence and protection to society citizen. This matter to free positive law of inequitable of law so that law remain to in progressive target.
\end{abstract}

Key words: J ustice, norm, positive law, progressive law, legislation.

\begin{abstract}
Abstrak
UU No. 48 tahun 2009 tentang Pokok-Pokok Kekuasaan Kehakiman Pasal 5 ayat (1) menyebutkan Hakim wajib menggali, mengikuti, dan memahami nilai-nilai hukum dan rasa keadilan yang hidup dalam masyarakat. hukum seharusnya dipahami secara luas sesuai dengan rasa keadilan dalam masyarakat. Hukum sesungguhnya bertujuan sosial, membela dan melindungi kepentingan warga Negara. Bila suatu teks hukum ditemukan berlawanan dengan tujuan sosial maka teks hukum harus dibaca dalam konteks substansi norma yang berhaluan sosial, rasa keadilan masyarakat, membela kepentingan rakyat dan melindungi warga Negara. Ini merupakan upaya pembebasan hukum positif dari ketidakadilan yang dirasakan masyarakat sehingga hukum tetap bertujuan progresif.
\end{abstract}

Kata kunci: Keadilan, norma, hukum positip, hukum progresif dan peraturan.

\section{Pendahuluan}

Studi terhadap positivisme hukum di Indonesia menjadi sangat penting saat ini di saat bangsa ini sedang dan selalu terus membangun peradabannya ke ranah yang sesuai dengan rasa keadilan masyarakat. Cakupan cara berpikir legalistis positivis dalam studi hukum telah memberi paradigma berpikir hukum bersifat analisis hukum semata atas suatu peraturan yang berlaku. Titik kebenaran adalah teks peraturan yang dikenal dengan peraturan perundangan (legislation). Hukum yang pada wujud sesungguhnya tak terbatas direduksi dalam batas tertentu, deterministik bahkan mekanistik bagi penegak hukum untuk dilaksanakan menghakimi peristiwa-peristiwa yang terjadi.
Positivisme telah melahirkan hukum dalam skesta matematika, menyelesaikan hukum yang terjadi dalam masyarakat berdasar apa yang tertulis dalam teks undang-undang, mengkristal di posisi binernya suatu teks lalu pembaca harus memahami di keadaan itu dan tidak dibolehkan untuk berpikir lain. Sementara para hakim memutus perkara dengan teks tersebut atas persoalan hukum yang dihadapi. Seperti halnya yang terjadi di Indonesia, hakim memutus perkara mengutamakan hukum tertulis sebagai sumber utamanya. Kelompok-kelompok hakim yang berpikir demikian dapat digolongkan sebagai suatu aliran konservatif. ${ }^{1}$ Produk

Lintong O. Siahaan, "Peran Hakim Dalam Pembaharuan Hukum di Indonesia", J urnal Hukum dan Pembangu-nan, 
hukum sendiri akan melahirkan formalistik semata di mana kepastian hukum menjadi ikon kebenaran. Keadilan adalah keadilan yang terdefinisi atas apa yang tertulis dan menutup diri atas keadilan yang selama ini tidak termaktub dalam suatu teks perundang-undangan. Teori ini mengidentikkan hukum dengan undang-undang. Tidak ada hukum di luar undang-undang dan satu-satunya hukum adalah undang-undang. ${ }^{2}$

Berdasarkan demikian, positivisme hukum harus dibebaskan dari kekakuan dirinya. Studi ini tidak untuk mempertentangkan suatu aliran hukum ataupun menempatkan positivisme hukum sebagai biang keladi kegagalan dalam pembangunan hukum di Indonesia. Tetapi dalam studi ini diharapkan ada pembebasan dari kekakuan yang terjadi dan dirasakan seringnya terjadi pembalikan dari keadilan yang diharapkan oleh rasa keadilan masyarakat. Oleh karenanya, tulisan yang berjudul Membebaskan Positivisme Hukum Ke Ranah Hukum Progresif (Studi Pembacaan Teks Hukum Bagi Penegak Hukum) sangatlah penting dan mendesak dipahami oleh penegak hukum.

Tulisan ini akan berupaya menjelaskan bagaimana pembebasan itu sebagai keharusan dalam dinamika hukum kita sekarang di Indonesia ke ranah progresif, yang pro rakyat, berhati nurani dan bermoral tanpa melepas tujuan-tujuan sosial hukum. Untuk itulah diperlukan cara pembacaan teks hukum agar hukum tidak dipandang sebagai peraturan semata dengan membatasi ruang gerak hukum atas segala prosedur hukum, tekstual prosedural dan mengabaikan kebenaran substansif.

\section{Pembahasan}

\section{Membebaskan Positivisme Hukum ke Ranah Hukum Progresif}

Memperharui pemahaman atas tekstual perundang-undangan agar sesuai dengan rasa keadilan masyarakat jauh lebih mudah daripada

Tahun ke 36 N0.1 Januari 2006, Jakarta: Fakultas Hukum Universitas Indonesia, hlm. 35

2 Rusli Muhammad, "Kajian Kritis Terhadap Teori Hukum Positif (Positivisme)", J urnal Hukum Respublica, Vol. 5, No. 2, Tahun 2006, Pekanbaru: Fakultas Hukum Universitas Lancang Kuning (Unilak), hlm. 222-223 merevisi, memperbaharui maupun menambah dan mengadakan peraturan perundang-undangan. Bahkan terkadang suatu perubahan UndangUndang tidak selalu yang terjadi lebih baik, terkadang lebih dilematis membawa persoalan baru, demikian juga melakukan revisi, aturan hukum menjadi tambal sulam yang pada akhirnya tidak berujung pada harapan keadilan masyarakat. Untuk itu diperlukan cara pandang baru dalam pemahaman terhadap butir Pasal undang-undang yang ada yang lebih menekankan pada tujuan-tujuan hukum itu dibuat. Kajian-kajian kritis hukum selama ini banyak menyoroti praktek hukum yang terjadi harus dianggap sebagai kegairahan untuk tetap berpatokan pada tujuan besar hukum yaitu menciptakan kebahagian-kebahagiaan yang sebanyak-banyaknya (the greatest happiness for the greatest number).

Kebanyakan selama ini, praktek hukum oleh penegak hukum yang terjadi di Indonesia seperti praktek lembaga pengadilan, kepolisian, kejaksaan dan praktisi hukum (kelompok pilar dari criminal justice system) cendrung selalu bertumpu pada pijakan berpikir legisme sebagai ciri utama dari positivisme hukum. Dalam hal ini, cara pandang hukum dilihat dari teleskop perundang-undangan belaka untuk kemudian menghakimi peristiwa-peristiwa yang terjadi. Praktek seperti ini bukan berarti harus selalu diartikan keliru dikarenakan legisme sendiri telah dan selalu memberikan arti dari kepastian hukum. Sementara kepastian hukum adalah keperluan yang mutlak dalam praktek hukum itu sendiri.

Laporan penelitian M. Syamsuddin menyatakan bahwa pola pikir yang bercorak positivistik dan yang non-positivistik pada tatanan praksisnya melahirkan kecendrungan hakim yang berbeda dalam melakukan pemaknaan atau penafsiran hukum dalam memutus perkara korupsi. Hasil penelitian membuktikan tipe pertama adalah tipe hakim tekstual dan tipe kedua adalah tipe hakim yang kontekstual. Implikasinya sering kali hakim tipe pertama menjadi sulit atau gagal dalam membuktikan unsur-unsur tindak pidana korupsi sehingga melahirkan pu- 
tusan yang bebas. ${ }^{3}$ Penelitian merekomendasikan agar mengeloborasi hukum progresif dalam pendidikan hakim. Tujuannya jelas agar para hakim memiliki pola berpikir progresif.

Bagi penstudi hukum yang melihat hukum bukan hanya dari segi normatif saja tetapi juga sebagai sebuah produk pemikiran manusia, sebuah undang-undang pada kenyataan sering memiliki kelemahan untuk menyampaikan keadilan itu sendiri. Baik karena terbatasnya suatu teks, ambivalensi antara satu aturan dengan yang lainnya, masuknya beberapa kepentingan dalam pembuatan suatu peraturan perundangundangan yang kepentingan mana sebenarnya bukan untuk tujuan idealisme hukum, sesungguhnya meng-harusnya ada suatu tinjauan kritis terhadap hukum.

Upaya pemecahan kebekuan teks-teks hukum telah dirasakan lama dalam studi hukum. Munculnya studi semiotika hukum seperti teori dekonstruksi dalam filsafat sering digunakan untuk memecahkan kebekuan suatu teks. Konsep ini ingin melihat teks senantiasa berkorelasi dan mempunyai konteks sehingga selalu mengandung kemungkinan arti-arti yang lain. Seperti halnya suatu penafsiran kontekstual yang ingin melihat hukum dalam konteks sosial atau pun dalam perspektif sosial maka teori-teori ini dianggap telah meluas pada ranah yang bukan lagi pada teks hukum. Gerakan studi hukum kritis atau Critical Legal Studies (CLS) di Amerika merupakan salah satu contoh dari keingininan untuk mencoba sebuah teori yang bertujuan melawan pemikiran yang sudah mapan khususnya mengenai norma yang standar yang sudah di built-in dalam teori dan praktek hukum yang ada selama ini. Diakui memang positivisme hukum telah banyak memberi sumbangan besar dalam pem-bangunan hukum modern di dunia. Namun bukan berarti ia tidak memiliki kekurangannya yang antara lain adalah telah mengabaikan substansi hukum yaitu keadilan dan ke-

\footnotetext{
${ }^{3}$ M. Syamsuddin," Rekonstruksi Pola Pikir Hakim Dalam Memutus Perkara Korupsi Berbasis Hukum Progresif", Jurnal Dinamika Hukum, Vol. 11 No. 1 J anuari 2011, Purwokerto: FH Universitas J enderal Soedirman, hlm. 11
}

manfaatan. ${ }^{4}$ Kajian hukum telah lama mengembangkan dirinya menuju ranah sosiologis, non-dogmatik yang sangat memungkinkan akan keluar dari maksud teks yang sesungguhnya.

Cara penafsiran hukum yang selama ini digunakan oleh aparat penegak hukum seperti kepolisian, kejaksaan dan lembaga peradilan adalah penafsiran sistematik. Suatu undang-undang merupakan legalitas mutlak beserta penjelasannya yang tidak dapat diartikan lain melewati suatu penafsiran. Ini merupakan ciri utama dari paradigma positivisme, di mana para pelaku hukum menempatkan diri dengan cara berpikir dan pemahaman hukum secara legalistik positivis dan berbasis peraturan (rule bound), sehingga dalam mengkaji hukum hanya aspek lahiriahnya saja yang diperhatikan sedangkan nilai-nilai atau norma yang muncul dari realitas sosial seperti keadilan, kebenaran, atau kebijaksanaan yang biasanya mendasari aturan-aturan hukum tidak mendapat tempat, karena tidak dapat dijangkau oleh penginderaan. ${ }^{5}$ Cara-cara inilah yang hingga sekarang terus diserang dan dikritik karena dianggap menjadikan hukum sebagai institusi pengaturan yang kompleks telah direduksi menjadi sesuatu yang sederhana, linier, mekanistik, dan deterministik terutama untuk kepentingan profesi dan berakhir dengan ketakmampuannya untuk mencapai kebenaran.

Desakan pemikiran hukum di Indonesia bisa dirasakan sehingga melahirkan Pasal 5 ayat (1) UU No. 48 tahun 2009 tentang Pokok-Pokok Kekuasaan Kehakiman bahwa Hakim dan hakim konstitusi wajib menggali, mengikuti, dan memahami nilai-nilai hukum dan rasa keadilan yang hidup dalam masyarakat. Dalam penjelasannya menyatakan Ketentuan ini dimaksudkan agar putusan hakim sesuai dengan hukum dan rasa keadilan masyarakat.

\footnotetext{
4 Yusriyadi, "Paradigma Positivisme Dan Implikasinya Terhadap Penegakan Hukum Di Indonesia", Jurnal hukum, Vol. 14, N0. 3, April 2004, Semarang: Fakultas Hukum Universitas Islam Sultan Agung (UNISSULA), hlm. 463

5 Erwin, "Upaya Mereformasi Hukum Sebagai Akibat Dominasi Positivisme Dalam Pembentukan dan Penegakan Hukum Di Indonesia", Jurnal Hukum Progresif Vol.1, N0.1, Juni 2007, Semarang: Program Doktor IImu Hukum Universitas Diponegoro, hlm.16
} 
Berdasarkan Pasal 5 ayat (1) dari UU No. 48 tahun 2009 diakui adanya kemungkinan ketaksempurnaan suatu teks hukum yang terbutir dalam Pasal Undang-Undang sehingga cendrung untuk tidak sesuai dengan rasa keadilan masyarakat. Hakim sebagai ujung tombak dalam proses litigasi pengadilan haruslah mencermati keadaan tersebut. Bagi kelompok yang melihat hukum dari perspektif sosial, ketentuan tersebut dianggap sebagai pembelaan terhadap pandangan mereka.

Terlepas dari perbedaan pendapat suatu aliran pemikiran di ranah ilmu hukum dogmatik maupun ilmu hukum non-dogmatik, ketidakadilan itu secara nyata masih dirasakan oleh masyarakat yang salah satunya dalam realitas teks hukum yang terbutir dalam beberapa Pasal undang-undang. Ada kenyataan yang terjadi, seringkali hukum terlihat menjadi bulan-bulanan dan permainan para praktisi hukum. Adanya mafia peradilan membuktikan kenyataan terseoknya hukum di tangan para penegak hukum. Persekongkolan antar para penegak hukum dengan para pencari keadilan baik di tingkat kepolisian, kejaksaan dan para hakim. Bahkan melibatkan advokat yang mendampingi di segala pemeriksaan. ${ }^{6}$

Ketidakadilan yang terjadi dalam penanganan hukum oleh penegak hukum adalah suatu ironi karena sesungguhnya wujud hukum itu sendiri bercita-cita keadilan (gerechtigkeit). Hukum telah diarenakan dalam konteksnya yang formal, mekanistik tanpa hati nurani sehingga menjadi mudah bagi para penegak hukum untuk melakukan perbuatan yang sekedar memenuhi kebutuhan formal meski harus bertentangan dengan rasa keadilan masyarakat. Hasil laporan penelitian Agus Raharjo dan Angkasa menyebutkan terjadinya kekerasan psikologis banyak dilakukan penyidik dengan maksud untuk mendapatkan pengakuan atau keterangan dari tersangka. ${ }^{7}$ Dalam konteks

\footnotetext{
6 Agus Budianto, "Tantangan Profesi Advokat Dalam Membangun Fair Trial", J urnal Hukum Gloria J uris, Vol. 8 N0.2, Mei 2008, J akarta: Fakultas Hukum Universitas Katolik Indonesia Atma J aya, hlm. 51

${ }^{7}$ Agus Raharjo dan Angkasa, "Profesionalisme Polisi Dalam Penegakan Hukum", Jurnal Dinamika Hukum, Vol.11
}

yang lain, bukan hanya polisi tetapi juga jaksa dan hakim melakukan prilaku yang bertentangan dengan keadilan. Sarjana hukum yang seharusnya berprilaku sesuai aturan hukum ternyata ikut andil melakukan kerusakan hukum. ${ }^{8}$ Terkadang teks hukum ditelusuri untuk mencari celah kekurangan yang pasti ada dalam suatu teks hukum untuk suatu kepentingan yang bukan demi untuk hukum, tidak untuk mencari dan menyempurnakan tujuan sosialnya dari hukum yang seharusnya responsif bagi keadilan masyarakat. Kekakuan teks hukum harusnya disempurnakan dengan upaya pembacaan teks hukum yang benar dan responsif. Tanpa hukum yang mampu menanggapi keadilan masyarakat (hukum responsif) maka hukum itu sendiri telah kehilangan rohnya. Rohnya hukum itu adalah moral dan keadilan. ${ }^{9}$ Untuk itulah diperlukan suatu kesadaran bagi penegak hukum bahwa hukum untuk manusia bukan sebaliknya. Hukum bukan dibuat karena sekehendak semata para penguasa atau hanya sekedar kepentingan golongan maupun kepentingan sesaat sekedar memenuhi formalisme hukum. Tetapi hukum amat ditentukan pada kemampuannya mengabdi pada manusia, bahkan merekayasa manusia pada kultur kehidupan yang berkeadilan.

Hukum progresif merupakan koreksi terhadap kelemahan system hukum modern yang sarat dengan birokrasi serta ingin membebaskan diri dari dominasi suatu tipe hukum liberal. Tujuannya agar para penegak hukum tidak melihat suatu peraturan atas apa yang tertulis saja. Seperti yang terjadi selama ini di mana penegak hukum telah terjebak dalam cara berhukum positivisme yang sempit dan kurang diliputi semangat untuk mengekspolorasi pemenuhan rasa keadilan yang lebih kontekstual. ${ }^{10}$ Hukum

No.3, September 2011, Purwokerto : Fakultas Hukum Universitas J enderal Soedirman, hlm. 383

${ }^{8}$ Dey Revena, "Konsepsi Dan Wacana Hukum Progresif", J urnal Hukum Suloh, Penelitian Dan Pengkaj ian Hukum, Vol. VII, NO. 1, April 2009, Aceh : Fakultas Hukum Universitas Malikussaleh (UNIMAL), hlm. 16-17

9 M. Husni, "Moral Dan Keadilan Sebagai Landasan Penegakan Hukum Yang Responsif", Jurnal Hukum Equality, Vol. 11, N0.1, Pebruari 2006, Sumatera Utara : Fakultas Hukum Universitas Sumatra Utara, HIm. 3

10 Ridwan, "Memunculkan Karakter Hukum Progresif Dari Asas-Asas Umum Pemerintahan Yang Baik Solusi Pencarian Dan Penemuan Keadilan Substantive", Jurnal 
dapat dilihat baik pada dirinya (secara dogmatif) maupun dalam perspektif di luar dirinya (non dogmatik). Di sini keharusan bagi penegak hukum untuk melihat bukan sekedar hanya menelaah bangunan logis-rasional dari deretan pasal-pasal peraturan secara formal dan prosedural (analytical jurisprudence) tetapi juga dalam perspektif sosialnya hukum yaitu aspek moral, hati nurani rasa keadilan masyarakat.

Kenyataan di atas dipahami betapa hukum itu bukan hanya bangunan peraturan biasa, namun disadari juga sebagai bangunan ide, kultur dan cita-cita. Keterpurukan hukum di Indonesia lebih dikarenakan penyingkatan hukum sebagai rule of Iaw tanpa melihat sebagai rule of morality. Akibatnya hukum hanya dilihat sebagai peraturan prosedur yang lekat dengan kekuasaan. Padahal di balik hukum juga sarat dengan nilai, gagasan untuk membangun kultur baru yang lebih kontekstual pada rasa keadilan masyarakat. Di sini akan terjadi suatu muatan hukum harus luas dalam cakupan moralitas. Hukum tertulis selama ini pasti tidak sunyi dari kesalahan dan pengabaian hati nurani, kultur dan cita-cita ideal manusia. Hukum progresif mengalaskan muatan hukum harus menggenapi kultur dan cita ideal manusia yaitu kebahagiaan. Kultur itu sendiri tidak lain adalah Indonesia yang menurut kacamata hukum progresif amat berbeda dengan pemberlakuan hukum modern yang masuk dan mempengaruhi hukum di Indonesia. Hukum modern disadari tidak mungkin dihapuskan namun ia perlu diberikan ruh kehidupan kultur Indonesia agar ia menjadi hukum yang Indonesia. Hukum yang sepadu hati nurani masyarakat sehingga hukum itu responsif yaitu hukum didasarkan pada kultur masyarakat itu sendiri.

Untuk menuju ranah hukum progresif, hukum diprinsipkan dalam konsep, sebagai berikut. Pertama, asumsi dasar hukum haruslah untuk manusia bukan untuk dirinya sendiri hukum itu diadakan. Jika hukum diperuntukkan untuk manusia seharusnya tidak memberlakukan masalah hukum itu menjadi masalah manusia (hu-

Hukum Pro J ustitia, Vol. 26 N0.2, April 2008, Bandung: Fakultas Hukum Universitas Katholik Parahyangan, hlm. 169 man problem), akan tetapi memperlakukan masalah manusia menjadi masalah hukum; kedua, hukum progresif tidak menerima hukum sebagai institusi yang mutlak serta final. Tidak berusaha untuk mereduksi hukum hanya sekedar peraturan-peraturan, akan tetapi suatu yang lebih besar dari itu yakni hukum diletakkan dalam kaitannya dengan kemanusiaan. Berdasar semangat untuk manusia, bukan berarti hukum yang ada semuanya adalah keliru tetapi perlu disempurnakan dari sebagai mesin otomatis menjadi bermanusia, berhati nurani pada kepentingan manusia itu sendiri yang terus berkembang. Maka hukumpun harus berkembang pula mengikuti dan membela kemanusiaan itu sendiri. Ketiga, hukum tidak boleh melepaskan dirinya dari tujuan sosialnya; keempat, hukum mengabdi kepada manusia karenanya tidak boleh mengabaikan hati nurani manusia; kelima, hukum harus bermoral. Hukum tak boleh memisahkan diri dengan moral. Hukum bukanlah sekedar peraturan biasa tetapi ia adalah bangunan ide, kultur dan cita-cita. Keterpurukan hukum di Indonesia lebih dikarenakan penyingkatan hukum sebagau rule of law tanpa melihat sebagai rule of morality; keenam, hukum progresif merupakan koreksi terhadap kelemahan sistem hukum modern yang sarat dengan birokrasi serta ingin membebaskan diri dari dominasi suatu tipe hukum liberal. Ketujuh, hukum harus selalu berada dalam proses untuk terus menjadi. Hukum adalah institusi yang secara terus-menerus membangun dan mengubah dirinya menuju kepada tingkat kesempurnaan yang lebih baik. Kualitas kesempurnaan itu bisa diverifikasi ke dalam faktorfaktor keadilan, kesejahteraan, kepedulian kepada rakyat dan lain-lain. Inilah "hakikat hukum yang selalu dalam proses menjadi" (Law as a process, law in the making); kedelapan, hukum progresif menolak tradisi analytical jurisprudence atau rechtsdogmatiek, dan berbagai paham atau aliran dengan legal realism, freirechtslehre, sociological jurisprudence, interessenjurisprudenz di Jerman, teori hukum alam, dan critical legal studies. Hukum progresif merupakan koreksi terhadap kelemahan sistem hukum modern yang sarat dengan birokrasi 
serta ingin membebaskan diri dari dominasi suatu tipe hukum liberal; kesembilan, interpretasi hukum progresif dengan hati nurani, melihat hukum bukan hanya dalam dataran yang tertulis dari teks formalnya tetapi juga pada teks non formal, pro-keadilan, pro-rakyat demi tegaknya tujuan sosialnya; dan kesepuluh, hukum progresif menerima hukum bukan hanya pada internal hukum itu sendiri tetapi lebih luas yaitu di luar dari hukum bahkan untuk membangun kehidupan dan kebahagian manusia.

Berdasar demikian, hukum yang ada yang berlaku di Indonesia melewati perbagai peraturan perundang-undangan harus dipahami bukan sekedar apa adanya tetapi seperti maksud Pasal 5 ayat (1) UU N0. 48 Tahun 2009 tentang Kekuasaan Kehakiman yaitu keadilan yang dirasakan masyarakat. Cara pembacaan terhadap aturan-aturan tersebut harus disiasati yaitu dengan kaca mata objektif progresif sehingga kekakuan hukum positif menjadi terbebaskan dari watak cacatnya agar keadilan dapat dirasakan oleh masyarakat.

Memperhatikan uraian di atas, Positivisme hukum dapat ditarik ke ranah hukum progresif yaitu bagian yang statis dari suatu teks Undang-Undang dapat dipahami secara progresif. Dalam kasus penindakan terhadap pelaku korupsi dapat dilakukan upaya-upaya yang tidak hanya bersifat prosedural tetapi kontekstual. Kerugian negara harus diterjemahkan dengan kerugian pada masyarakat, tidak hanya angka dalam arti ekonomi tetapi juga kebijakan yang merugikan rakyat. Penyalahgunaan jabatan harus dipahami sebagai indikasi motif kejahatan meski untuk tujuan itu pelaku telah menutupinya dengan berbagai prosedur administratif. Bahkan suatu kejahatan yang sulit dijangkau dengan tekstual butir pasal undang-undang (invisible crime) dipastikan dapat dijerat hukum.

\section{Membaca Teks Hukum Dalam Hukum Progresif Bagi Penegak Hukum}

Sejak hukum membuat tradisi untuk dituliskan (written law), maka pembacaan teks hukum menjadi masalah yang penting. Penafsiran terhadap teks hukum tak dapat dihindar- kan. la seperti jantung hukum dan tak dapat dijalankan melainkan dengan membuka penafsiran. Hal ini disebabkan suatu teks yang tertulis memiliki kekurangannya untuk dapat mencakup atas segala hal peristiwa yang mungkin terjadi ataupun suatu yang tidak lagi relevan atas perkembangan zaman. Selain upaya melakukan suatu revisi atas undang-undang adalah dengan mengganti suatu peraturan perundang-undangan yang baru. Upaya ini tentu saja melewati suatu proses yang lama dan prosedural yang rumit. Upaya lain yang lebih mudah dan cepat adalah dengan melakukan penafsiran hukum terhadap teks peraturan perundang-undangan.

Pemahaman terhadap hukum yang bertumpu hanya pada analitical jurisprudence dengan mendasari diri pada ilmu hukum dogmatik sering menghasilkan hukum yang statis. IImu hukum dogmatik selalu hanya melihat ke dalam hukum dan menyibukkan diri dengan membicarakan dan melakukan analisis ke dalam, khususnya hukum sebagai suatu bangunan peraturan yang dinilai sebagai sistematis dan logis. Jadi, kegunaan dari ilmu hukum dogmatis ini tidak lebih hanya menelaah bangunan logis-rasional dari deretan pasal-pasal peraturan. Oleh karenanya, ilmu hukum dogmatik seperti ini juga lazim disebut dengan analytical jurisprudence, ${ }^{11}$ yang dalam praktiknya sangat bertumpu pada dimensi bentuk formal dan prosedural dalam berolah hukum untuk mencapai (aksiologi) kepastian, yang benar dan adil adalah peraturan hukum itu sendiri. Kebalikan dari itu, ilmu hukum non-dogmatik sebagai dasar dari hukum progresif tidak berhenti kepada menyibukkan diri dengan bangunan logis-rasional dari sebuah peraturan.

Kenyataan sekarang ini, penafsiran hukum oleh penegak hukum pada umumnya masih bersifat tekstual didasarkan ilmu hukum dogmatik. Baik ditingkat kepolisian, kejaksaan mau pun di lembaga peradilan. Dalam beberapa kasus yang ditemui oleh penulis di lapangan sebagai praktisi hukum, seorang warga yang me-

\footnotetext{
${ }^{11}$ Satjipto Rahardjo, "Hukum Progresif, Hukum yang Membebaskan", Jurnal Hukum Progresif, Vol. 1, No. 1, April 2005, Semarang: Program Doktor IImu Hukum Universitas Diponegoro, hlm. 7.
} 
laporkan pencurian kendaraan bermotor oleh tetangganya sendiri dengan modus operandi menyewa kendaraan bermotor tersebut. Kemudian korban melaporkan kejadian tersebut kepada pihak berwajib (Polisi). Tetapi polisi menolak laporan tersebut dikarenakan pelapor tak dapat mem-buktikan surat sewa menyewa kendaraan dengan dasar Pasal 372 dan 378 KUHP yaitu penggelapan dan penipuan. Ini jelas sangat melawan rasa keadilan masyarakat yang secara jelas kendaraan bermotornya diambil tetangganya sendiri di depan mata dengan modus penyewaan kendaraan. Bentuk penyewaan sendiri hanya bersifat adat kebiasaan setempat (tanpa ada bukti otentik). Penolakan polisi saat itu sesungguhnya hanya karena memahami KUHP secara tekstual, statis tanpa memahami progresnya. ${ }^{12}$ Harusnya dipahami, Pasal 362 KUHP (pencurian), 372 KUHP (penggelapan) dan 378 KUHP (Penipuan) sebenarnya memiliki tujuan yang sama yaitu menghilangkan barang orang. Pasal-pasal tersebut sesungguhnya hanyalah menunjuk modus operandi pelaku kejahatan. Oleh karenanya, seharusnya polisi menerima laporan warga dan secara tuntas menyelesaikan kasus tersebut dengan menetapkan Pasal 362 KUHP, sebagai perbuatan; tindak kejahatan pencurian yang harus dihukum. Cara pembacaan ini progresif dan sesuai dengan harapan rasa keadilan masyarakat untuk dilindungi dari kejahatan.

Demikian juga kasus laporan masyarakat tentang penipuan oleh pelaku bisnis dengan modus operandi investasi usaha. Di berbagai daerah di Indonesia kenyataannya pelaku tak

\footnotetext{
${ }^{12}$ Adhi Wibowo menambahkan bahwa sisi lain masyarakat sangat rnenaruh harapan yang besar pada polisi untuk tidak hanya menyelesaikan kasus-kasus (tindak pidana) saja tetapi juga harus marnpu mernberikan perlindungan (pengayoman) kepada siapa saja yang terlibat atau berkaitan dengan tindak pidana yang terjadi. Namun terkadang harapan tersebut tidak dapat dipenuhi, malah justru perilaku oknum polisi yang tidak simpatik yang sering dijumpai di lapangan, kondisi ini berakibat memunculkan kekecewaan bagi masyarakat. Lihat, Adhi Wibowo, "Peranan Kepolisian Dalam Memberikan Perlindungan Terhadap Saksi Dalam Perspektif Criminal Justice System", Jurnal Hukum Respublica, Vol. 5 No. 2, Pekanbaru : 2006, Fakultas Hukum Universitas Lancang Kuning, hlm. 253
}

dapat dijerat dengan hukum. Alasan pihak kepolisian adalah hubungan mereka bersifat keperdataan sehingga tak dapat dipidanakan pelakunya. Kasus transaksi Multi Level Marketing (MLM), bisnis Voucher telepon seluler, Investasi Usaha yang terjadi di banyak daerah dengan merekrut ribuan manusia bernilai milyaran rupiah tak dapat dilaporkan ke pihak berwajib (Polisi) lantaran tidak ada bukti tertulis kecuali kontrak kerjasama. Dengan alasan kasus tersebut bersifat keperdataan maka pelaku tak dapat dijerat dengan Pasal-pasal pidana. Sebut saja dengan alasan Pasal Penipuan atau perbuatan curang (378 KUHP) maka akan diperoleh kenyataan di mana unsur-unsur pidana dalam butir Pasal tidak ditemukan. Pasal 378 menentukan bahwa

Barangsiapa dengan maksud untuk menguntungkan diri sendiri atau orang lain secara melawan hukum, dengan memakai nama palsu atau martabat palsu, dengan tipu muslihat, ataupun rangkaian kebohongan, menggerakkan orang lain untuk menyerahkan barang sesuatu kepadanya, atau supaya memberi hutang maupun menghapuskan piutang diancam karena penipuan dengan pidana penjara paling lama empat tahun.

Unsur Pasal ini dalam penjelasannya harus terpenuhi semua yaitu ada unsur menguntungkan diri atau orang lain, perbuatan melawan hukum, memakai nama palsu atau martabat palsu, adanya tipu muslihat atau rangkaian kebohongan, menggerakkan orang lain untuk menyerahkan barang kepadanya. Ini merupakan unsur yang lengkap yang biasa dipenuhi dalam menjerat pelaku. Namun dalam kasus seperti investasi bisnis, unsur-unsur tersebut selalu tak mungkin terpenuhi. Misalnya investasi bisnis (sebut saja usaha tertentu) adalah pekerjaan saling menguntungkan bukan sepihak. Perbuatannya sendiri tidak melawan hukum karena disadari atas kerelaan bersama sesuai dengan causa yang halal. Tidak ada memakai nama palsu atau martabat palsu maupun tipu muslihat. Namun pada kenyataannya, pelaku telah memutar uang dari sekian banyak orang untuk diberikan keuntungan dalam beberapa bulan. Kemudian pelaku membuktikan dirinya sedang 
bankrut dalam usaha. Sementara ribuan orang telah menginvestasikan uangnya kepada pelaku. ${ }^{13}$

Pihak berwajib sebenarnya berpikir dalam pola progresif, pelaku dapat dikenakan Pasal 378 KUHP dengan alasan adanya unsur persamaan modus operandi terhadap banyak orang. Perbuatan tersebut dirasakan telah nyata merugikan orang lain dengan melawan hukum (Onrechtmatige daad). Banyaknya pihak yang mengadu atau melaporkan dan dapat dibuktikan pelaku telah berulang-ulang melakukannya. Sedemikian pula para hakim yang memeriksa perkara tersebut dapat secara progresif menilai dan menghukum pelaku dikarenakan perbuatannya yang melawan hukum telah merugikan orang lain secara melawan hak sebagai perbuatan sengaja dilakukan oleh pelaku. Dengan demikian, tidak diperlukan pembuatan UU baru tentang kejahatan dengan modus operandi tersebut yang pada gilirannya terlalu banyak aturan akan menyulitkan suatu tuntutan dan akan menjadi bulan-bulanan praktisi hukum di Pengadilan untuk melepaskan diri pelaku kejahatan.

Kasus sebaliknya adalah kasus pencurian sebiji buah semangka karena kehausan di jalan lalu dituntut oleh JPU dengan mengenakan Pasal 362 KUHP tentang pencurian, demikian pula kasus Nenek Minah asal Banyumas dianggap telah mencuri 3 buah biji kakao yang mengakibatkan ia divonis 1,5 bulan kurungan adalah salah satu contoh bertentangan dengan rasa keadilan masyarakat. Kasus seperti demikian atau sebaliknya tindak pidana berat dihukum ringan, ${ }^{14}$ ternyata banyak terjadi di berbagai

13 Di Banjarmasin, beberapa kasus investasi seperti kasus voucher (2006), investasi usaha berlian (2008), investasi kebun kelapa (2010) tak tertangani dengan progresif meskipun banyak laporan penipuan terhadapnya, pelaku tak dapat dijerat dengan Pasal Pidana KUHP.

14 Krismiyarsi, melaporkan atas kenyataan yang terjadi dalam hal tindak pidana pencurian kayu jati yang seharunya dikenakan sanksi pidana Para178 ayat 4 UU No. 41 tenrang Kehutanan dengan pidana penjara paliing lama 10 tahun dan denda paling banyak $\mathbf{5}$ milyard rupiah. dalam praktiknya seringkali hanya dijatuhi hukum pidana jauh dari ancaman minimal bahkan dapat dikatakan terlalu ringan, akibatnya pelaku tak merasa jera untuk mengulangi perbuatannya. Lihat, Krismiyarsi, "Dampak Negatif Pemidanaan Yang Terlalu Ringan Terhadap Pelaku daerah. Pasal dalam peraturan perundang-undangan (362 KUHP) dijadikan remote kaku atas segala peristiwa dan peroblem hukum. Pencurian telah dipahmi secara statis adalah mengambil barang milik orang lain. Ini berakibat orang yang sedang kehausan sekedar untuk menghilangkan hausnya di tengah sawah dengan mengambil sebiji semangka dianggap sebagai pencurian atau 3 biji kakao juga pencurian. Padahal dimaksudkan suatu pencurian bila dipahami secara progresif adalah suatu perbuatan yang sengaja dilakukan untuk dimiliki dengan nilai berharga pada umumnya di masyarakat. Tidak ada satupun masyarakat menilai hilangnya sebiji semangka dari pemilik ratusan atau ribuan buah semangka adalah suatu kerugian. Seperti halnya juga tiga biji kakao yang dianggap tak berharga oleh pelaku dikarenakan pemilik mempunyai ribuan atau tak terhitung jumlah biji kakao. Pencelaan masyarakat terhadap pengaduan pemilik yang merasa barangnya dicuri dalam kasus tersebut membuktikan terjadi rasa ketidak adilan dalam hati nurani masyarakat. Seharusnya pihak berwajib tidak menjeratnya dengan Pasal pencurian. Cukup memberinya peringatan agar tidak mengulangi perbuatannya. Tujuannya agar tidak terjadi tindakan yang berulang-ulang. Demikian pula jaksa seharusnya mengenyampingkan tuntutan atau menolak pengaduan Polisi. Cara lain, jika per-kara ini telah disidangkan, diperiksa hakim maka manjelis hakim dapat memutuskan pembebasan bagi terdakwa karena secara progresif apa yang dilakukan terdakwa bukanlah suatu pencurian dimaksud dalam Pasal 362 KUHP.

Hal sebaliknya terjadi pada kasus korpusi. Banyak terdakwa kasus korupsi yang terus terjadi di beberapa Pengadilan Tipikor di daerah dalam lima tahun terakhir ini membuat persoalan sendiri dalam penegakan keadilan di negeri ini. Tingginya korupsi di Indonesia telah menyebabkan semua sistem dan sendi kehidupan bernegara rusak karena praktek korupsi

Pencurian Kayu Jati", Jurnal Hukum dan dinamika masyarakat, edisi Okt 2004, Semarang : Fakultas Hukum Universitas Tujuh Belas Agustus 1945, hlm. 1 
telah berlangsung secara merata. ${ }^{15}$ Hakim yang berpikir tidak dengan pengetahuan hukum substantif adalah hakim yang berpola pikir statis, tekstual dan tak memahmi progresif suatu pasal. Biasanya suatu putusan bebas didasarkan dengan alasan bahwa tidak cukup terbukti untuk menjerat terdakwa. Padahal biasanya proses penyidikan terhadap masalahl korupsi sudah sangat hati-hati, bukan hanya dugaan kuat atau sekedar adanya bukti permulaan (Pasal 1 angka 14 KUHAP) ataupun syarat formil dan materilnya (Pasal 143 ayat (2) huruf a dan b KUHAP), tetapi juga bukti-bukti yang teruji dalam penyidikan pihak Penyidik Tipikor kepolisian atau Jaksa Tipikor sehingga dilakukan suatu penuntutan, meyakinkan dan sesuai dimaksud suatu tuntutan terhadap tindak pidana korupsi.

Demikian pula pada kasus perdata seperti kasus ganti rugi tanah masyarakat akibat lumpur Lapindo di Porong Sidoarjo, ${ }^{16}$ banyaknya masyarakat tak diganti hak tanah mereka dikarenakan mereka hanya memiliki bukti "beschikkingsrecht" seperti segel, atau girik, sporadik apalagi yang tidak memiliki surat-menyurat namun telah menempatinya secara turun-temurun. Pihak perusahaan hanya mengganti tanah-tanah yang memiliki sertifikat. Alasannya sesuai dengan Pasal 19 UU No.5 Tahun 1960 bahwa tanah hak milik harus telah terdaftar di Badan Pertanahan Nasional (BPN). Masyarakat juga telah melakukan gugatan ganti rugi ke Pengadilan dan tetap saja hak-hak mereka tidak diakui. Padahal jika hakim progresif, adanya tanah adat juga diakui dalam UU No. 5 Tahun 1960. ini artinya tidak boleh menge-

${ }^{15}$ Noor Aziz Said, "Aspek-Aspek Sosiologik System Hukum Nasional (Tinjauan Kritis Terhadap Kasus Bank Century)", Fakultas Hukum Universitas Jenderal Soedirman, Purwokerto : Jurnal Dinamika Hukum, Vol. 10, No.3, September 2010, hlm. 221

16 Mukhamadun melaporkan atas peristiwa yang terjadi dalam tragedi lumpur Lapindo bukan hanya masyarakat yang dirugikan tetapi juga lingkungan. Untuk itu dia mengusulkan agar diterapkan Prinsip plluters must pay berdasar UUPLH terhadap pelaku perusakan untuk mengganti atau Perampasan keuntungan yang diperoleh dari tindak pidana, perbaikan akibat tindak pidana, termasuk pergantian atas kerusakan lingkungan maupun terhadap masyarakat sekitar. Lihat, Mukhamadun, "Lumpur Lapindo Akar Masalah Dan Solusinya Dalam Perspektif Hukum Lingkungan", Jurnal Hukum Respublica, Vol. 6, N0. 1, 2006, Pekanbaru : Fakultas Hukum Universitas Lancang Kuning, hlm. 18 nyampingkan hak kepemilikan adat hanya karena adanya Pasal 19 UU No. 5 Tahun $1960 .{ }^{17}$ UU Pokok Agraria sesungguhnya hanya untuk menertibkan tentang kepemilikan tanah di samping guna persoalan agraria. Terlebih dalam prakteknya pembuktian yang bersifat "beschikkingsrecht" seperti segel atau girik dan sporadik merupakan alas hak untuk pendaftaran tanah milik (pembuatan sertifikat). Sementara itu pula, permohonan warga agar beroleh ganti rugi bukanlah seng-keta kepemilikan tanah tetapi suatu keadaan di mana secara nyata mereka di rugikan oleh perusahaan sebagai penyebab terjadinya musibah lumpur Lapindo. Akibat berpola pikir hukum yang statis hingga sekarang ada ribuan kepala keluarga yang tak memiliki tempat tinggal bahkan sebagiannya tidak punya pekerjaan hanya lantaran mereka tak dapat membuktikan kepemilikan tanah berupa sertifikat. Harusnya hakim berani untuk bersikap afirmatif (affirmatif law enforcement) yaitu keberanian untuk melakukan pembebasan dari praktek statisnya dan melakukan teroboson terhadap hukum yang ada demi kemanusiaan, prorakyat dan hati nurani. ${ }^{18}$

Hukum seharusnya aktif berperan untuk dan sebagai motor pembangunan kehidupan masyarakat dalam tujuan sosialnya, kehidupan yang ideal dan melindungi serta mengabdi pada manusia. Betapa pentingnya hukum sesuai dengan kebutuhan masyarakat, budaya dan spiritual masyarakat. Sedang kenyataan hukum po-

17 Menurut Elita Rahmi, tanah diekploitasi untuk kepentingan spekulasi dan pembangunan yang kurang berpihak kepada rakyat, harus diwaspadai baik secara preventif dan refresif oleh sistem perundang-undangan Nasional. Selanj utnya dalam persoalan tanah harus pula dilihat aspek kearifan lokal dan adat istiadat setempat. Elita Rahmi, "Eksistensi Hak Pengelolaan Atas Tanah (HPL) Dan Realitas Pembangunan Indonesia", Jurnal Dinamika Hukum, Vol. 10, N0. 3, September 2010, Purwokerto: $\mathrm{FH}$ Universitas J enderal Soedirman, $\mathrm{hlm}$. 340 dan 344

${ }^{18}$ Muhammad Fauzan membuktikan Putusan MK No. Nomor: 41/ PHPU. D-VI/ 2008 merupakan teroboson hukum karena hakim bukan corong Undang-Undang tetapi memiliki keluasan dalam memutuskan perkara yang merupakan cerminan dari kemandirian dengan mendasarkan pada nilai-nilai keadilan dan perasaan hukum yang tumbuh dan berkembang dalam masyarakat. Lihat, Muhammad Fauzan, "Terobosan Hukum Mahkamah Konstitusi: Analisis Tentang Putusan MK Nomor: 41/PHPU.D-VI/2008", Jurnal dinamika hukum, Vol. 9, N0.1, 2009, Purwokerto : Fakultas Hukum Universitas J enderal Soedirman, hlm. 9 
sitif selama ini masih menyisakan problem. Hukum positif modern yang dipakai oleh bangsa Indonesia dikembangkan tidak dari dalam masyarakat Indonesia melainkan ditanamkan dari luar (impposed from outside). Hukum modern adalam produk sosial, ekonomi, dan kultural barat, khususnya Eropa. Pemberlakukan hidup manusia secara sama tanpa diskriminatif merupakan ikon dalam hukum produk barat menjadikan tidak ada pembelaan terhadap orangorang kecil dan lemah karena semua orang harus diberlakukan sama.

Tumbuhnya sistem hukum modern dalam perspektif studi hukum kritis, sangat dipengaruhi oleh konvergensi antara paradigma positivisme dalam ilmu pengetahuan alam, dengan kapitalisme sebagai ideologi ekonomi dan perilaku. Dalam kontruksi pemikiran paradima positivisme, maka perangkat ketentuan hukum diyakini sebagai perangkat yang bersifat netral, tidak berpihak dan harus diberlakukan secara impersonal (tidak subjektif). ${ }^{19}$ la dijaga karena dianggap mampu mengamankan kebebasan individu. Perangkat aturan hukum tersebut kemudian melahirkan cara berpikir analitical jurisprudence di mana para hakim dan semua orang yang memahami hukum terhadap persoalan hukum mengidentifikasikan pada prinsip dan aturan yang relevan secara deduktif tanpa perspektif lain darinya. ${ }^{20}$ Ini juga menciptakan formalisme hukum tanpa disadari di mana keadilan di luar dari perspektifnya adalah bukan keadilan. Semua orang dianggap sama (homogen) dan harus diberlakukan hukum yang sama dengan seperangkat prosedur yang diciptakan

19 M. Manelia, "Kritik Terhadap Hukum Modern Dalam Perspektif Studi Hukum Kritis", Jurnal Hukum Perbankan Dan Kebanksentralan, Vol. 6, No. 2, 2008, J akarta : Direktorat Hukum Bank Indonesia, hlm. 37

20 M. Syamsuddin menawarkan pentingnya pendekatan holistik dalam kajian hukum dapat bersifat internal maupun eksternal. Yang internal diperlukan untuk mengintegrasikan berbagai pendekatan yang ada yang sama-sama mengkaji hukum sebagai objek kajian. Yang ekternal diperlukan untuk mengintegrasikan berbagai pendekatan di luar objek kajian ilmu hukum yaitu terhadap disiplin ilmu-ilmu lain yang berobjek bukan hukum. Lihat, M. Syamsudin, "Posisi IImu Hukum Di Tengah Perkembangan Berbagai Paradigma Keilmuan: Arti Pentingnya Pendekatan Holistik Dalam IImu Hukum", Jurnal Hukum Respublica, Vol. 6 No.1, 2006, Pekanbaru : Fakultas Hukum Universitas Lancang Kuning, hlm. 62-63 oleh hukum itu. ${ }^{21}$ Maka yang terjadi adalah adanya pihak orang-orang yang lemah menjadi korban atas keadilan itu. Hal yang senyatanya keadilan yang tumbuh dan ada dalam realitas tidak semuanya teridentifikasi dalam perspektif formalisme.

Optik sosiologis menunjukkkan, masyarakat bukanlah komunitas yang homogen melainkan sebaliknya. Masyarakat penuh dengan perbedaan, penggolongan, dan stratifikasi. Adanya keluhan masyarakat betapa orang-orang kuat dapat Iolos dari jeratan hukum, terjadinya mafia hukum membalikkan fakta hukum dengan memainkan aturan prosedural dan permainan hati nurani masyarakat atas nama hukum. Hukum juga dapat digunakan elit politik untuk kepentingan politiknya. Ironi pula penciptaan hukum berupa undang-undang sering di awali dengan tawar-menawar kekuasaan bukan untuk kepentingan kebahagiaan masyarakat. Orangorang kuat dapat membuat dan memenuhi tembok formalisme hukum dalam hukum yang ditulis.

Perubahan sosial yang terjadi tidak mampu terjawab oleh hukum. IImu hukum dalam status quo hukum itu sendiri. Hukum dirasa tidak mampu lagi menjawab. Perkembangan ini terjadi khususnya dalam negara civil law seperti Indonesia. Hukum diposisikan untuk hukum bukan untuk manusia. Bangsa dan negara di dunia masing-masing memiliki tradisi nilai yang berbeda-beda. Oleh karenanya transfer hukum modern yang notabene berasal dari Barat yang individualistik dan liberalistik berbeda dengan kosmologi Indonesia. ${ }^{22}$ Atas kenyataan demi-

${ }^{21}$ Wibisono Oedoyo dalam penelitiannya mengatakan bahwa Pengaruh Aliran positivisme terjadi juga pada setiap putusan pengadilan dapat terlihat dimana ia memfokuskan diri pada norma hukum yang terbebas dari intervensi disiplin ilmu lain seperti sosiologi, sejarah, politik, psikologi, filsafat dan agama. Lihat, Wibisono Oedoyo, "Beberapa Prinsip Penerapan Teori Hukum Yang Dikemukakan Aliran Positivisme Dalam Putusan MA RI No. 02 K/ N/ 1998", J urnal Hukum Themis, V0l.2 N0.1, Oktober 2007, Jakarta : Fakultas Hukum Universitas Pancasila, hlm. 35

${ }^{22}$ C. Maya Indah S, "Refleksi Sosial Atas Kelemahan Hukum Modern: Suatu Diseminasi Nilai Kebenaran Tradisi Dalam Citra Hukum Indonesia", J urnal Masalah-Masalah Hukum, Vol. 37, N0. 3, 2008, Semarang: Fakultas Hukum Universitas Diponegoro, hlm. 167 
kian, diperlukan pembenahan dalam memahami hukum yang tertulis dengan cara menerobos kebekuan dan kekakuan dalam penciptaan keadilan yang sesungguhnya yaitu rasa keadilan yang ada dalam realitas sosial dengan kultur masyarakat dan perkembangan sosial mereka maupun individu dalam menemukan prasaan keadilan mereka.

Tidak ada alternatif lain disementara tuntutan sosial hukum seperti sekarang ini telah menjadi kekuatan di mana sering terjadi konflik antara hukum yang hidup di masyarakat dengan aturan hukum tertulis. Sengketa yang diselesaikan di depan pengadilan di mana hakim berhukum dengan hukum yang relevan atas suatu peraturan perundang-undangan sering tidak dapat memuaskan masyarakat yang lemah dan marginal dikarenakan kealpaan mereka dalam memahami hukum tertulis. Untuk itu diperlukan cara strategis dalam pembacaan teks hukum agar terbebas dari kekakuan dan rasa keadilan masyarakat. Pembacaan teks hukum menjadi urgen bagi penegak hukum dalam segala lapisan agar hukum dalam praktik menjadi sesuai dengan hati nurasi rasa keadilan masyarakat Indonesia. Cara tersebut dapat meliputi cara berpikir dalam pembacaan, terutama dilakukan oleh penegak hukum, berupa: pertama, melihat teks hukum harus tidak dilihat sebagai yang berdiri sendiri tetapi harus dipahami maksud atau tujuan besar dari pembuat teks hukum atau undang-undang (legislation); kedua, setiap teks hukum selalu memiliki tujuan dan objek yang ingin dicapainya, untuk itu perlu memahami lebih jauh apa yang dimaksudkan dari suatu pasal hubungannya dengan tujuan besar dari diberlakukannya suatu undang-undang. Cara pembacaan ini sering diungkap sebagai pembacaan teks atas substantif hukum. Ketiga; meyakini adanya kemungkinan kesalahan teks atas suatu hukum karena berlawanan dengan rasa keadilan masyarakat. Dengan kata lain harus berani mengetengahkan ide objektif hukum yaitu keadilan sosialnya bukan sekedar apa yang tertulis pada teks hukum; keempat, berani mengkritik teks hukum untuk suatu kesempurnaan pelaksanaan hukum, menggali ke- adilan sekalipun di luar teks hukum demi moral, keadilan sosial dan hati nurani rakyat.

\section{Penutup \\ Simpulan}

Para hakim, jaksa, polisi harus berani membaca teks hukum dengan makna yang lebih luas secara progresif, yaitu menempatkan pada konteks sosial dan tujuan sosial masa kini. Tidak sedikit teks undang-undang yang malah bisa mengganggu rasa keadilan di masyarakat apabila tidak dibaca dan dimaknai secara progresif. Atas kenyataan itulah disadari benar oleh pembuat undang-undang di negeri ini sehingga diberlakukan UU No. 48 Tahun 2009 tentang Kekuasaan Kehakiman Pasal 5 ayat (1) yang menentukan bahwa (1) Hakim dan hakim konstitusi wajib menggali, mengikuti, dan memahami nilai-nilai hukum dan rasa keadilan yang hidup dalam masyarakat.

Berdasar hal tersebut, dapat dipahami dan disimpulkan beberapa hal berikut ini. Pertama, pembebasan positivisme hukum dapat dilakukan dengan cara melakukan pembacaan teks hukum ke ranah hukum progresif yang bermaksud untuk meninggalkan pola kekakuan yang ada dalam setiap butir Pasal dalam undang-undang; kedua, pembacaan teks hukum ke ranah hukum progresif dapat dilakukan dengan melakukan strategi cara berpikir yang selalu mengundung unsur kontekstual, unsur berperasa rasa keadilan masyarakat, unsur hati nurani, moralitas, holistis, komprehensif memahami keseluruhan suatu undang-undang dan peraturan lain yang berhubungan dengannya termasuk hukum adat serta memahami tujuan substansi dari suatu hukum seperti untuk manusia dan sebesar-besarnya untuk kebahagiaan manusia, pro-rakyat dan keadilan bagi masyarakat.

\section{Saran}

Beberapa saran yang dapat diberikan kepada penegak hukum adalah sebagai berikut. Pertama, diperlukan pendidikan yang berorentasi pada pemahaman hukum progresif bagi para penegak hukum di semua lingkungan peradilan bagi para hakim, di lingkungan kepo- 
lisian dan kejaksaan. Setidaknya bagi para caIon hakim, calon jaksa dan para polisi yang akan menjadi penyidik maupun pembantu penyidik; kedua, muatan hukum progresif juga harus diperkenalkan dan diajarkan dalam kurikulum Fakultas Hukum dan Syariah sehingga berbasis hukum progresif. Setidaknya ada mata kuliah seperti kecakapan memahami undang-undang secara progresif untuk mahasiswa hukum di semester akhir

\section{Daftar Pustaka}

Budianto, Agus. "Tantangan Profesi Advokat dalam Membangun Fair Trial". J urnal Hukum Gloria Juris, Vol. 8 N0.2. Mei 2008. J akarta: Fakultas Hukum Universitas Katolik Indonesia Atma Jaya;

Erwin. "Upaya Mereformasi Hukum Sebagai Akibat Dominasi Positivisme Dalam Pembentukan dan Penegakan Hukum Di Indonesia". J urnal Hukum Progresif. Vol. 1. No.1. J uni 2007. Semarang: Program Doktor IImu Hukum UNDIP;

Fauzan, Muhammad. "Terobosan Hukum Mahkamah Konstitusi: Analisis Tentang Putusan MK Nomor: 41/ PHPU.D-VI/2008". Jurnal Dinamika Hukum Vol. 9 No. 1. 2009. Purwokerto: Fakultas Hukum UNSOED;

Husni, M. "Moral dan Keadilan Sebagai Landasan Penegakan Hukum yang Responsif". J urnal Hukum Equality. Vol. 11, N0.1 Pebruari 2006. Sumatra Utara: Fakultas Hukum USU;

Krismiyarsi. "Dampak Negatif Pemidanaan yang Terlalu Ringan terhadap Pelaku Pencurian Kayu Jati". Jurnal Hukum dan Dinamika Masyarakat, edisi Okt 2004. Semarang: Fakultas Hukum Universitas Tujuh Belas Agustus 1945;

Manelia, M. "Kritik Terhadap Hukum Modern dalam Perspektif Studi Hukum Kritis". Jurnal Hukum Perbankan Dan Kebanksentralan. Vol. 6. No. 2. 2008. J akarta: Direktorat Hukum Bank Indonesia;

Muhammad, Rusli. "Kajian Kritis Terhadap Teori Hukum Positif (Positivisme)". Jur-nal Hukum Respublica. Vol. 5. No. 2 Ta-hun 2006. Pekanbaru: Fakultas Hukum Universitas Lancang Kuning (Unilak);

Mukhamadun. "Lumpur Lapindo Akar Masalah Dan Solusinya Dalam Perspektif Hukum
Lingkungan". Jurnal Hukum Respublica. Vol. 6. N0. 1. 2006. Pekanbaru: Fakultas Hukum Universitas Lancang Kuning;

Oedoyo, Wibisono. "Beberapa Prinsip Penerapan Teori Hukum yang Dikemukakan Aliran Positivisme dalam Putusan MA RI No. 02 K/N/ 1998". Jurnal Hukum Themis, Vol. 2 No. 1 Oktober 2007. Jakarta: Fakultas Hukum Universitas Pancasila;

Rahardjo, Satjipto. "Hukum Progresif, Hukum yang Membebaskan". J urnal Hukum Progresif. Vol. 1. No. 1 April 2005. Semarang: Program Doktor IImu Hukum Universitas Diponegoro;

Raharjo, Agus dan Angkasa. "Profesionalisme Polisi Dalam Penegakan Hukum". Jurnal Dinamika Hukum. Vol. 11 No. 3. September 2011. Purwokerto: Fakultas Hukum UNSOED;

Rahmi, Elita. "Eksistensi Hak Pengelolaan Atas Tanah (HPL) dan Realitas Pembangunan Indonesia". J urnal Dinamika Hukum. Vol. 10 No. 3. September 2010. Purwo-kerto: FH UNSOED;

Rasjidi, Lili. "Peranan Hukum dalam Pembangunan Nasional Indonesia dalam Hukum Responsif". Jurnal Hukum Review. Vol. 01 No. 01. 2005. Bandung: Fakultaas Hukum Universitas Padjadj aran;

Revena, Dey. "Konsepsi Dan Wacana Hukum Progresif". Jurnal Hukum Suloh, Penelitian Dan Pengkajian Hukum. Vol. VII, N0. 1, April 2009. Aceh: Fakultas Hukum Universitas Malikussaleh (UNIMAL);

Ridwan. "Memunculkan Karakter Hukum Progresif Dari Asas-Asas Umum Pemerintahan Yang Baik Solusi Pencarian Dan Penemuan Keadilan Substantive". Jurnal Hukum Pro Justitia. Vol. 26 N0.2. April 2008. Bandung: Fakultas Hukum Universitas Katholik Parahyangan;

S., C. Maya Indah. "Refleksi Sosial Atas Kelemahan Hukum Modern: Suatu Diseminasi Nilai Kebenaran Tradisi dalam Citra Hukum Indonesia". Jurnal Masalah-Masalah Hukum. Vol. 37. N0. 3. 2008. Semarang: Fakultas Hukum Universitas Diponegoro;

Said, Noor Aziz. "Aspek-Aspek Sosiologik Sis-tem Hukum Nasional (Tinjauan Kritis Terhadap Kasus Bank Century)". Jurnal Dinamika Hukum Vol 10, No. 3 September 2010. Purwokerto: Fakultas Hukum Universitas J enderal Soedirman; 
Siahaan, Lintong O. "Peran Hakim Dalam Pembaharuan Hukum di Indonesia". J urnal Hukum dan Pembangunan. Tahun ke 36 N0.1 Januari 2006. Jakarta: Fakultas Hukum Universitas Indonesia;

Syamsuddin, M. "Rekonstruksi Pola Pikir Hakim Dalam Memutus Perkara Korupsi Berbasis Hukum Progresif". Jurnal Dinamika Hukum. Vol. 11 No. 1 Januari 2011. Purwokerto : FH Universitas Jenderal Soedirman;

Syamsudin, M. "Posisi IImu Hukum Di Tengah Perkembangan Berbagai Paradigma Keilmuan: Arti Pentingnya Pendekatan Holistik Dalam IImu Hukum". Jurnal
Hukum Respublica. Vol. 6 No.1. 2006. Pekanbaru: Fakultas Hukum Universitas Lancang Kuning;

Wibowo, Adhi. "Peranan Kepolisian Dalam Memberikan Perlindungan Terhadap Saksi Dalam Perspektif Criminal Justice System". J urnal Hukum Respublica. Vol. 5 No. 2. 2006. , Pekanbaru: Fakultas Hukum Universitas Lancang Kuning;

Yusriyadi. "Paradigma Positivisme Dan Implikasinya Terhadap Penegakan Hukum Di Indonesia". J urnal hukum, Vol. 14. N0. 3. April 2004. Semarang : Fakultas Hukum Universitas Islam Sultan Agung (UNISSULA). 